\title{
Conflict, Militarization, and Their After- Effects: Key Challenges for TESOL
}

\section{CYNTHIA D. NELSON}

The University of Sydney

Sydney, Australia

\section{ROSLYN APPLEBY}

University of Technology Sydney

Sydney, Australia

\begin{abstract}
Skyrocketing military spending, ongoing military conflicts, and human displacement worldwide have significant consequences for the teaching and learning of English. TESOL increasingly requires a robust research base that can provide informed, critical guidance in preparing English language teachers for work in and near conflict zones, for teaching refugees and asylum seekers, and, more broadly, for teaching English in highly militarized times. This investigation, which takes the form of a transdisciplinary, translocal literature review, consolidates and extends TESOL's peace-conflict studies through a close examination of two areas that are connected but rarely considered in tandem: TESOL's multiple involvements and entanglements in armed and militarized conflicts and their aftermath, and the challenges of teaching English in a conflict zone or for students who have escaped or been exiled from one. Implications for pedagogy and further research are suggested. The argument is, in short, that the dialectical relationship between TESOL and conflict is in urgent need of collegial scrutiny, that teachers need to be equipped to facilitate critical and creative engagement with English not apart from broader sociopolitical realities but in relation to these, and that the implications of conflict for language learning are relevant across the wider TESOL community, given world developments.
\end{abstract} doi: 10.1002/tesq. 187

ver the past decade, military spending worldwide has more than doubled, to an astounding US $\$ 1.75$ trillion in 2012 (with $39 \%$ of that amount spent by the United States alone; Perlo-Freeman, Sköns, Solmirano, \& Wilandh, 2013). The human consequences of this intensified militarization are difficult to quantify, but it does seem telling that over the same decade the number of people worldwide who have 
been forcibly displaced has also more than doubled, to an estimated 45.2 million people by the end of 2012 (United Nations High Commissioner for Refugees, 2013a). That staggering figure-which includes refugees, internally displaced persons, and asylum seekersamounts to nearly the entire population of Spain or South Africa and does not include the legions of people living in or near high-conflict zones or under military occupation. Although this profound destabilization at a global level has urgent implications for education in general, our focus here is the TESOL community, because English is playing a significant role in many militarized conflict situations and their aftermath.

In the field of TESOL, there is a growing need for teachers who are prepared for the particular challenges of classes that are not only metaphorical contact zones (Pratt, 1999) but are situated in literal conflict zones. This would include teachers already living in a conflict zone as well as those heading into one for work or returning home to teach after training elsewhere. Increasingly, the field also needs teachers in any location to have the know-how to support the learning of "conflict-affected people" (Kagawa, 2005, p. 496) who have escaped or been expelled from a conflict zone and are studying English while rebuilding their lives. This would include not only teachers who knowingly work with refugees and asylum seekers but also teachers who may not realize that some of their students have refugee pasts. But even TESOL practitioners and scholars who themselves never end up teaching in a conflict zone or teaching displaced students, we would argue, must be knowledgeable about militarization, displacement, and what these currently mean for the field. Large- and small-scale conflicts, and the migratory flows that accompany these, are placing new and greater communicative demands on virtually everyone-from aid workers to asylum seekers, from soldiers to ordinary citizens, both near and far from conflict sites - and these in turn place new demands on language learning and teaching. Hence the need for greater collegial understandings and open discussions of how armed and militarized conflicts and their aftermath are reshaping the pedagogies, policies, and geopolitics of the TESOL field.

There is clearly some concern about these issues across the TESOL community (some members of the international TESOL organization, for instance, have formed Interest Sections on refugee concerns and on social responsibility, with peace a core topic). In terms of research, existing studies of English language education in relation to conflict have shed light on important matters such as the uses of English in promoting propaganda and/or building solidarity (Karmani, 2005a, 2005b; Kramsch, 2005; Nasser, Berlin, \& Wong, 2011); language policies and education practices in conflict-ridden areas (Appleby, 2010; 
Cadman \& Brown, 2011; Woods, 2005); the challenges facing displaced learners and their teachers (Tshabangu-Soko \& Caron, 2011; Wachob \& Williams, 2010; Windle \& Miller, 2012); and ways of teaching about language, war, and peace (Benesch, 2010; Morgan \& Vandrick, 2009).

Although a number of studies examine English language education in relation to conflict, militarization, and their legacies and after-effects, this work has not yet been brought together as an acknowledged research area. Collectively, this body of literature, which we propose be called TESOL's peace-conflict studies, provides an empirical and scholarly basis for engaging with challenging issues that are increasingly part of day-to-day teaching and teacher education in many parts of the world. This work also helps the wider TESOL community at large keep abreast of the language and education implications of some of the most crucial and far-reaching issues of our time: war, militarized conflicts, security, postconflict reconstruction, displacement, and the like. Also commendable, much of the peace-conflict research has been undertaken by teacher-researchers who are working in difficult conditions, often with marginalized populations, and in an undervalued, underfunded area of research. Still, much work remains to be done.

Our investigation aims to consolidate, strengthen, and extend TESOL's peace-conflict studies by illuminating two pressing matters that are rarely considered in tandem: (a) TESOL's involvements in militarization in conflict zones and in peacekeeping efforts in post-conflict zones, and (b) the effects of conflict on the education experiences of English language learners and teachers while living in conflict zones and afterward.

To elaborate, the first part of our investigation draws together studies that consider English language policies and TESOL practices in zones of war, militarized conflict, occupation, postconflict reconstruction, and peacekeeping (McBeath, 2006; Sproat, 2002; Woods, 2005). Such studies are valuable and timely, but there is a tendency to describe local practice, often in just the one locality or geo-region; few of these studies reach across geographic contexts so as to discern, or critically discuss, larger patterns of practice or thought-hence, the value in drawing the studies together. We also draw on studies that examine links between the global spread of English on the one hand and forces of militarization and colonialism on the other (Edge, 2003; Elyas, 2008; Karmani, 2005a, 2005b; Kramsch, 2005), though generally such studies give little in-depth attention to learning or teaching. Thus, our investigation maps out some key challenges for TESOL in relation to the teaching and learning of English for military purposes during war and conflict and for peacekeeping purposes in their aftermath. 
We then examine studies of the challenges affecting the education of those living in a conflict zone as well as those who have fled or been exiled from one (MacPherson, 2005; Mareng, 2010; Wachob \& Williams, 2010). These studies, too, are valuable and timely, but in each the focus tends to be on one or two individuals or language programs, which again limits the ability to discern or critically discuss patterns or themes of relevance across education sectors and sites. So the second part of our investigation outlines some common effects of conflict on the education experiences of English language learners in and from high-conflict zones and of their teachers.

We then comment briefly on the implications of these discussions for English language pedagogies in and after conflict, outline some key knowledge gaps, and offer ideas for further pedagogic exploration and research.

We want to emphasize that our comments about the limitations of the existing literature are not at all intended as criticisms of individual studies. Quite the contrary; it is because much work has been done, and done so diligently, that the field is now in a position to expand peace-conflict studies so that it can help prepare the TESOL field for the even greater needs to come. Building a useful knowledge base in TESOL for collegial exchange, peer scrutiny, and creative innovation will require rigorous cross-site analyses that can map out, extend, and even challenge current practice and thinking. It will require some conceptual tools to help frame and deepen discussions of practice. It will also require increasingly more inventive approaches to teaching and research, and a wider cross-section of the global TESOL community will need to be not just informed but actively involved.

To investigate the challenges facing TESOL as a result of conflict, militarization, and their after-effects, we have undertaken an extensive literature review that is transdisciplinary, trans-sectoral, and transnational. It draws together an otherwise disparate collection of research studies from second and foreign language education, applied linguistics, and language policy, augmented by research from related fields such as international development, peace and conflict studies, refugee studies, and education. We have supplemented this research literature with what we are calling professional literature - material drawn from popular journalism (such as teacher interviews, news items, blog postings), organizations' websites, and curriculum materials - which we have each been gathering for some years. We use this not as data per se but to augment the research literature in this rapidly changing area. Collectively, the literature we cite covers a range of primary, secondary, tertiary, and adult education/training sectors, from a wide variety of geopolitical settings. 
As a result, our key points are illustrated with examples gleaned from many studies, which means it is not feasible to provide detailed accounts of each study's context, methods, and so on. Though this approach has its limitations, it allows us to do two important things: to map out key challenges that recur across diverse sectors and sites and, ultimately, to draw out insights from one locale that might be adapted for use in others. Though there is no simple, universal panacea for the complex challenges we outline, we do suggest pedagogic and research directions that may better support learners and teachers who, whether through choice or necessity, find themselves grappling with conflict, militarization, and their direct effects.

\section{KEY CONCEPTS}

A crucial conceptual tool that serves as a backdrop to the discussions that follow is what Kagawa (2005), with a nod to Paulo Freire's work, has called "a dialectical relationship between schooling and armed conflicts" (p. 489, italics added). Education can be a "contributor to conflict" (p. 490), a mouthpiece of the military, a weapon of war, and a source of soldiers; conversely, it can be a place of refuge from conflict, a safe haven, even a site of protest. Two examples illustrate these contrasts. According to Kim-Rivera's (2002) historical study, when Korea was under Japanese colonial rule (from early to mid-20th century), English was declared "an enemy language" (p. 279), which meant that English language programs and activities (speech contests, publications) were banned, study in (and travel to) English-speaking countries was prohibited, and students were turned into soldiers. In that scenario, English language education was effectively disbanded in the service of militarization. By contrast, Shakhshir's (2011) study of education (not specifically English language education) under military occupation shows that it can be configured and conceptualized as a space for protest and resistance. Shakhshir observes that, for Palestinians, "motivation for learning increased during the period of both Intifadas. In addition, teachers and students managed to resume the educational process despite ... [enforced school] closures ... [and] the universities became a model for resistance" (p. 16).

Though it is not possible to offer definitive solutions to the problems we identify, with this study we hope to at least advance the scholarly discussion of conflict, militarization, and TESOL in important directions. Most significantly, our investigation seeks to foster more, and more critically informed, discussions about TESOL's educationconflict dialectic: how TESOL programs are currently positioned, and 
how TESOL stakeholders think they ought to be positioned, in relation to conflict, war, peace, and militarization.

As to our key terms, we use conflict to refer not to interpersonal conflict but to conflict on a larger scale - battles and clashes involving military forces, police, armed insurgents, and the like. We use militarization primarily to refer to the processes and actions associated with the literal presence of military soldiers and other military workers. Though we value conceptions of militarization that also include militaristic thinking and discourse in popular culture, civic life, and so on (see Sutton \& Novkov, 2008) - notions with rich pedagogic and analytic potential for TESOL - these lines of thought are not our focus here. We use after-effects in two ways: to refer to the place-based aftermath of war, conflict, and military occupation (that is, reconstruction, peacebuilding, and peacekeeping) and to refer to the enduring effects for those who have lived through conflict scenarios, even after the conflict has abated or the person has relocated. Lastly, we use TESOL to refer to the broad field of English language teaching and research, not specifically the international organization of the same name.

\section{TESOL'S INVOLVEMENTS IN CONFLICT AND POSTCONFLICT ZONES}

In its role as an international language, English is being used in a variety of ways in militarized conflict zones, in regions adjacent to direct conflict, and in the long processes of postconflict turmoil and reconstruction. In these domains, English is in demand as an international language that facilitates both military work and development work, two arenas that are historically linked and often co-located (Clarke, 2006; Duffield, 2002). English also serves as an intranational language between internally displaced people (Norton \& Kamal, 2003).

The broader context for these uses of English is what Woods (2005) and others have called the Fourth World War (the Cold War being the third), which is, in effect, a series of ongoing wars waged against ethnic insurgents, so-called terrorists, and other forces considered antistate. These wars rely on international cooperation between states that may have no common language, so English has been adopted as a means to improve interoperability among military and security forces from diverse language backgrounds (Woods, 2005, p. 95). This has given rise to an educational subfield called English for military purposes (EMP; see McBeath, 2006) and the associated professional occupation of military language instructor. 
The need for military-specific curricula and teacher support, given the general dearth of these matters in TESOL's professional and research fora, is evident in comments like this one, from a teachers' online discussion forum:

I have taught EFL [English as a foreign language] in Saudi Arabia for 12 years, all but 1 in military EFL.... Not many of even the so-called "professionals" in the EFL field appreciate just how different military students' needs are compared to those in regular classes. (Aquanaut, 2006)

In some zones of military conflict, English is being taught to military, security, and civilian populations through the English Centre of the U.S. Defense Language Institute and through the Peacekeeping English Project of the British Council. The latter project (whose materials were taken offline in 2010) provided English language instruction to military personnel, police, and border guards, and professional development for teachers of these cohorts; Woods (2005) gives examples of projects undertaken in Hungary, Lithuania, and Romania. To give a flavor of the Peacekeeping English curriculum, below is an excerpt from the teachers' guide for the first unit of lessons on the "British Army Organisation"; the answers expected of students are shown in upper case and underlined.

\section{Student Worksheet}

Listen to the tape through once without stopping.... Listen a second time and complete the worksheet....

6. What is the task of armoured reconnaissance?

TO OBSERVE AND REPORT ON THE MOVEMENT OF THE ENEMY.

7. Complete this list of infantry tasks:

Engage the enemy and DESTROY HIM AT CLOSE QUARTERS. (British Council, n.d., p. 9)

Although this excerpt raises questions about what exactly constitutes peacekeeping English, it gives a sense of the mechanistic approach to language and to learning that seems to characterize much of the military-related material. (For a somewhat different slant, see Nesyn's 2011 account, presented at a language teaching conference in Ukraine, of applying "the communicative approach" to teaching English for military purposes - more specifically, the giving of military briefs, which is 
described as "one of the most important activities of the intelligence officer," p. 154.)

In addition to the British Council's various training programs for defense forces in Asia and Africa (see, e.g., British Council, 2013, on its work in Namibia), the Australian Defence Force also funds English language programs for foreign military personnel from Southeast Asia, the Pacific, and the Middle East (Department of Defence, 2012). Also, military language institutes have been established in the United Arab Emirates to prepare that country's military personnel "to communicate effectively in English ... in the performance of their military duties" (AMIDEAST, n.d., para. 4) and also in Kazakhstan to increase the English language skills of that country's military personnel with the aim of "enhancing Kazakhstan's links with the NATO Alliance" (McDermott, 2005, para. 1).

These developments have led, in turn, to new resource materials to support teaching and learning in EMP. Prominent among these has been Campaign, a series of English course books that were designed for military personnel engaged in international operations (and that won the British Council ELT Innovation Award in 2005). English has also been promoted as a means for civilians living in conflict and postconflict zones to engage with peacekeeping operations, transnational agencies (such as the United Nations and World Bank), international aid agencies, and development workers. This has been the case in countries such as Afghanistan (Tran, 2002), Cambodia (Clayton, 2008), and East Timor (Appleby, 2010; Brunnstrom, 2003; Hajek, 2000), where the delivery of humanitarian aid relies on English as a common language of communication.

English language programs have also been offered as a "secular" contribution to Islamic education systems in regions associated with, or adjacent to, armed conflict and terrorist insurgency (see AusAID, 2007; Elyas, 2008). Moreover, in the wake of the first and second Gulf Wars, development funds have been directed to educational projects in which English language teaching plays a role in "supporting higher education" (see USAID/Afghanistan, 2014). The British Council offers English language courses in several of the Gulf Arab states, and there are now American Universities of Afghanistan, Iraq, and Kuwait, which offer foundational English language courses as well as English-only instruction in degree programs. According to a lecturer in English at Kabul University (which is not one of the American Universities, though its extensive library was reportedly funded by the United States), in Afghanistan there is a high demand for English "because we have a lot of international staff, both civilians and military in our country, and they need people to speak English, especially those who 
want to have a high salary and work with them as translators and interpreters" (Arditti, 2006, para. 9).

Certain tertiary institutions extend an existing network of American Universities throughout the Middle East (Rupp, 2009) that have been positioned, on the one hand, as "agents of change in the Arab world" (Council on Foreign Relations, 2007, para. 2) and, on the other hand, as institutions that are "useful to Washington in the extension of soft power and US cultural influence" (Woolf, 2010, para. 7).

These various roles for English have particular implications for teachers and learners who are already living in or near a conflict zone (Canagarajah, 1993; Norton \& Kamal, 2003; Sproat, 2002); those who have been stationed in, or are preparing to move to, a conflict zone for work (Appleby, 2010; Gaffey, 2005; Templer, 2003); those who prepare resource materials for use in conflict zones; and those who have become refugees by escaping or being expelled from such a zone.

Karmani (2005a, 2005b), for example, argues that ELT programs, and by implication English language teachers, serve the interests of military and postmilitary intervention in the oil-rich Gulf Arab states, where the "war on terror" may be seen as a battle between Islam and English. In a similar vein, Edge (2003) expresses concern that overt military imposition in the Middle East by the United States, the United Kingdom, and Australia "threatens fundamentally to recast the role of English language teachers ... [who] may now explicitly be perceived as a second wave of imperial troopers ... facilitating the policies that the tanks were sent to impose" (p. 703, italics added). In this regard, Syed (2003) notes that the majority of English language teachers in the Gulf states, particularly at tertiary level, are North Americans, Britons, and Australians. Noting the "dizzying pace" of EFL teaching in Gulf states, Templer (2003) predicted a boom in the "lucrative market for EFL being opened up by our generals" following the invasion of Iraq (p. 1). However, he also argued that this raises questions about "the politics of EFL in a conquered land" and warned that the EFL profession "needs to (re)interrogate its vested interest and central role in the maintenance and reproduction of the [English language] empire" (p. 2). Indeed, as governments devolve responsibility for postconflict reconstruction and development to commercial operations, significant profits can be made both by the corporate contractors who win tenders for project work and by expatriate language educators engaged to deliver projects in the field (Coffey, 2008; Gilligan, 2012).

Something similar is mentioned on a popular website for English language teachers called One Stop English in a post by a teacher (nationality unnamed) who went to Croatia to teach English: 
Rather than finding myself in a perilous situation, I found myself in a favourable one. The country had been plunged into economic and political depression and its people were faced with only one way out: to invest in themselves. For many, this meant learning or improving their English, the language of commerce and tourism. As I began my career here [in Zagreb], I could not help but think of myself as some kind of linguistic mercenary, here to cream off the spoils of war. (Anonymous, n.d., para. 1, italics added)

To counter linguistic imperialism as an accompaniment to military occupation, there have been calls for "an academic boycott or moratorium on expatriate teacher recruitment" (Templer, 2003, p. 3). There have also been calls to raise awareness of these matters among teachers and students and to reject monolingualism and the privileging of native speakers in order to better integrate EFL in local cultures in occupied territories (Gaffey, 2005). Expatriate teachers of English are urged to critically consider the sociocultural dimensions of their practices (Syed, 2003) and to engage directly with learner experiences and specific issues arising from violent conflict (Faiq, 2005a, 2005b). It is not only teachers whose first language is English who are implicated in these debates. For example, from a Saudi point of view, Elyas (2008) observes that, although the discourses inherent in EFL may conflict with Middle Eastern values, English is nevertheless a crucial aspect of Arab agency: "After 9/11, the need to learn English in order to understand what is being said and written about Arabs is present more than ever" (p. 44).

In sum, though TESOL's multiple (and contestable) roles in militarized conflict and postconflict peacekeeping are still not widely recognized in the field at large, they should be: these involvements and investments are vast in scope and varied in nature. As we have shown, they include English language programs sponsored not only by education institutions but also by military bodies, international aid agencies, and government departments. Moreover, the teaching of English (especially for military purposes) is complicated by perceptions that its spread is associated with imperialism, surveillance, and profit.

\section{CHALLENGES FOR LEARNERS AND TEACHERS DURING AND AFTER CONFLICT}

Having looked at the uses of English language programs in enabling military action, security efforts, and postconflict reconstruction, we turn now to the on-the-ground difficulties that English language learners and teachers are experiencing during conflicts and afterward. 
In the previous section, we noted the infusion of English language programs in certain conflict-affected regions, including Iraq. A teacher at a boys' high school in Iraq describes some of the challenges that he and his colleagues routinely encounter:

The textbooks are out of date and the government doesn't have the money to fund education after all the security concerns.... We also don't have a qualified generation of English teachers who are up to standard to teach. I have to be careful speaking English in the street too-some people will assume English speakers are working for the government and target us.

(Talib, 2006, paras. 5-7)

This comment highlights the financial hardships for education due to the intensive funding requirements of conflict and its aftermath. It also underscores the urgent need for more trained English language teachers (a common theme in the literature) but at the same time the dangers facing teachers - and, by implication, learners - in light of the troubled associations of English with colonialism and surveillance, as discussed above.

Another challenging issue that recurs in the literature is how student learning is hindered in areas rife with violence and danger. This next quote is from a teacher working "in close proximity to a war-ravaged community" on the U.S.-Mexico border (Munter, McKinley, \& Sarabia, 2012, p. 60). The students in this bilingual Spanish-English program at a middle school are described as "current/recent witnesses to armed conflict" (p. 52):

I don't think that our principals realize what's going on, other than, these kids don't speak English so they don't get good grades. But I don't think it's because they [the Ciudad Juárez children] don't speak English, I think it's because they worry about so many other things.... I'll talk to [the kids] ... and they'll tell me why they're not doing their [school] work.... [B] ecause they don't understand, because they're frustrated, because their mom was kidnapped, because their dad died on the weekend. (quoted in Munter et al., 2012, pp. 55, 57-58)

This teacher went on to say that many of the teachers in her school seemed to have very little idea about how to relate to the students as individuals and engage them in learning activities.

This raises another recurring theme: the lack of teacher expertise (and professional development opportunities) as to how to best identify and address the learning/language needs of students in conflict zones. This lack of know-how can be exacerbated when teachers have been brought into a conflict situation whose cultural geography is new and unfamiliar to them, which is not unusual in English language teaching contexts (see Cadman \& Brown, 2011). 
Scores of people who have been uprooted by armed and militarized conflict are living in refugee camps, where some are studying English. Mareng (2010), born in Sudan, lived at the Kakuma refugee camp, which is in Kenya near the Sudan border and which in 2008 housed nearly 50,000 refugees. Mareng reports that the "lack of English-speaking teachers" was a problem, especially beyond beginner levels of English (p. 475). He also notes the many material challenges of education at the camp; for example, given the size of the camp, some students "had to walk up to 10 kilometers in the blazing sun" just to get to class; without enough buildings, classes held outdoors had to be cancelled in inclement weather; and due to food shortages, the students "ate once a day in the evening," so being hungry during class made learning "really difficult" (p. 477). Although some students considered it "a miracle" to have an opportunity to go to school, others were dissatisfied: "Many of these students dreamt of becoming professionals and the education they were receiving seemed inadequate to meet their goals" (p. 477). Girls were especially disadvantaged; according to Mareng, many were kept at home so that they would not be exposed to "the kind of critical thinking encouraged by education" (p. 479). (Other researchers attribute the low percentage of girls attending refugee camp schools - less than $10 \%$ at another Kenyan camp, Dadaab, near the Somali border - to the high risk of sexual violence; daughters are kept home for their protection; see Bigelow, 2010.)

The vast majority of refugees-currently, over $80 \%$ worldwide - are being hosted by developing countries (United Nations High Commissioner for Refugees, 2013b). As a result, the high number of refugees in some cities presents particular challenges for those wanting to learn or better their English. A case in point is Cairo, with about 4 million refugees among its 20 million residents. A study of English language programs for mostly Sudanese "transitional refugees" living in Cairo outlines the numerous educational difficulties these students encounter while awaiting permanent resettlement (Wachob \& Williams, 2010, p. 596). Motivation and desire for English is strong among this cohort, both because the government of South Sudan is replacing Arabic with English as the medium for instruction there and also because many expect to eventually be resettled in an English-speaking country. However, given the high numbers of refugees wanting to study the language, training enough teachers is a major problem:

Many refugee teachers who lack a tertiary-level education, formal teacher training, and high-level English language skills are themselves faced with the same basic economic, political, social, psychological, and emotional challenges as their students.... [A] large majority [of the teachers in refugee schools] shares this profile. Not 
only does this make it difficult for teachers to prepare and offer quality lessons, it also means that most teachers do not have the tools to work independently to develop lessons and to better their teaching skills.

(Wachob \& Williams, 2010, p. 600)

In addition, in crowded Cairo simply finding physical spaces that can be used as classrooms is a major challenge. Getting to and from English classes safely can be a problem too. Wachob and Williams (2010) report that "many refugees from sub-Saharan Africa have very negative experiences with the Egyptians" (p. 598) and that "venturing outside living areas or refugee centers puts refugees at risk from the local population or police" (p. 599). Because so many refugee children and youth have been orphaned or separated from family members, there are also "focus and discipline problems in the classroom" and high dropout rates (p. 599). Again, it is noted that refugee women often face even more education obstacles than their male counterparts, and those who are mothers find it hard to attend class due to the lack of childcare.

Even after resettlement, learning can continue to be impeded due to the after-effects of torture and trauma. In the early 2000s more than 4,000 nuns were expelled from Tibet; this is the broader context of MacPherson's (2005) study of how five female Tibetan nuns in bilingual Tibetan-English classes in Dharamsala, India, negotiated the "extralinguistic reality" of "life in exile" (p. 604). One of the students, Tsepal, had been imprisoned and tortured in Tibet and "like many survivors, suffered from a litany of physical and psychological aftereffects" that seriously impeded her ability to pursue English and an education (p. 596):

The alienation arising from occupation, political persecution, imprisonment, and torture ... can leave courageous women like Tsepal much more than a refugee in body; they can become refugees in mind ... [experiencing] deep anger, illness, and even mental anguish.

(MacPherson, 2005, pp. 596-597, italics added)

Tsepal missed most of her classes. In her words: "I meet recent arrivals from Tibet and hear about the brutalities in prison and the killings, and I start to worry and get sick again" (p. 597). Few ESL programs are designed specifically for adult refugee trauma survivors, a point noted in Finn's (2010) study of just such a program in New York City (where, apparently, it is not uncommon for refugees to have to wait up to 2 years before a place in an adult ESL course becomes available).

This raises another recurring theme in the literature: that teachers located outside of high-conflict settings are often ill-prepared for the 
challenges of teaching refugees who arrive from war-torn countries. An Australian ESL teacher quoted in Ollerhead's (2010) study spent long hours creating class materials that she hoped would engage her students from "strife-torn regions," but was frustrated that her efforts often met with long silences in class (p. 610). Flummoxed about how to get discussions going, she blamed the students for being "passive learners" (p. 614). An illuminating example of this teacher getting "little or no response" from her class of refugee students was when she asked whether they go to the beach (p. 614); in Appleby's (2009) study of English language teaching in postconflict East Timor, a similar question about beaches was asked (also by an Australian teacher), and it turned out that the students refused to go near the beaches because during the period of militarized occupation these had become places of torture, where people were forcibly held under water.

Thus, configuring English classes as safe havens and productive spaces for students who are rebuilding their lives after conflict is no easy task (perhaps especially when students' literacy levels are low [Windle \& Miller, 2012]). Teachers require support as they develop expertise in this, and TESOL's peace-conflict research ought to serve as a resource that can enhance their professional development.

Few studies seek out the views of refugee and other displaced students on their English language classes and teachers, or their learning preferences and aspirations. A notable exception is TshabanguSoko and Caron's (2011) study. Through focus groups and interviews (with language interpreters) they investigated the perspectives of a group of Somali Bantu and Burundi refugees on their survival English classes (which were taught by teachers with no TESOL qualifications) in the United States. Though the students (mostly women) were reluctant to appear ungrateful, when pushed for their views they acknowledged that their teachers rarely spoke to them in ways that they could understand and the classes were not helping them learn English at all, despite their need and great eagerness to do so. In this case, it seemed that the students wanted English as a means for employment, but the program was not geared vocationally and did not seem to include any negotiation or even elicitation of the students' own learning aims; a related problem was "weak curriculum design" (p. 428). Bilingual learning support was also desired, which underscores the value of "encouraging refugee populations to train as teachers" (Tshabangu-Soko and Caron, 2011, pp. 427-428).

Clearly, conflict creates a number of challenges that can impede the ability to focus on learning (or teaching) English. These include immediate material challenges; lingering health issues; and the ongoing hardships of life amid extreme violence, poverty, and social 
alienation. Problems like these can seem daunting, even intractable, and beyond the capacities of the TESOL community to address. We would argue that teachers need to at least be cognizant of such problems, given their likely effects on learning opportunities and outcomes for students in, from, or headed to conflict zones. Moreover, TESOL practitioners and researchers must attend fully to those aspects that do fall clearly within our purview; this includes pedagogy and teacher education, which are discussed next.

\section{PEDAGOGIC APPROACHES AND RESEARCH DIRECTIONS}

In this section we draw on the above discussions to sketch out some key pedagogic and research implications, which are necessarily selective because there are many needs and possible directions for future work.

In terms of pedagogy, in the case of conflict-affected students there is a clear and urgent need for approaches that are relevant and responsive to students' learning needs and aspirations, which can involve communicating effectively with students at their level of language comprehension, giving students a say in class objectives and methods, and scaffolding active engagement in learning. This can involve skillfully and sensitively reconfiguring lived experiences into learning material as well as guiding students in learning to unpack the language and discourses of local and global issues of interest, including potentially conflictual associations with English. Education can serve as a rehumanizing influence, to counter the dehumanization that characterizes war and conflict situations; thus, it is also important to help (re)build a sense of community and connection, and to recognize and foster resourcefulness, resilience, and creative expression.

Most significantly, the design and practice of English language teaching in, for, and from conflict zones-as elsewhere-should not be concerned solely with linguistic objectives in a narrow decontextualized sense, but rather should equip students for critical communicative engagement with events occurring in the world outside the classroom and in the wider sociopolitical sphere (see Appleby, 2005/2006, 2010; Coleman, 2011; MacPherson, 2006; Toh, 2003). Although any teaching ideas must be tailored to suit the particular geo-region, education level, learning needs, and so on, in the following paragraphs we suggest a few macro-strategies (borrowing a concept from Kumaravadivelu, 2003). 


\section{Make Learning Participatory}

As Baynham (2006) notes, much TESOL literature is about trying to bring the outside into the classroom, but in his transcriptbased study of English classes for adult refugees and asylum seekers in the United Kingdom, "the outside presses in on classroom interaction" (p. 38). The classroom environment that results is "less docile [but] more open-ended" (p. 38), being characterized by "student agency" and dialogic learning opportunities "grabbed in passing" (p. 25).

With a participatory approach, students learn to claim space in conversations by speaking out and are active in negotiating class aims, content, methods, and/or interactions. They are invited (though certainly not required) to share aspects of their lived experience, their immediate real-life language needs, and their aspirations, and in this way the English language class is co-created as a supportive, resourceful community. Because participatory approaches to learning are not necessarily familiar (or desirable) to students across diverse cultural and education backgrounds (see Leshem \& Trafford, 2006), the processes of negotiation may need to be explicitly guided, which is itself a valuable learning opportunity (for teachers as well as students). For more, see Appleby (2005/2006, 2010), Windle and Miller (2012), and seminal work by Wallerstein (1982).

\section{Use Critical Discourse Inquiry}

In teaching an ESL reading class at a New York City college, Benesch (2010) sought to problematize the on-campus military recruitment of her students, who were from Egypt, Nigeria, Pakistan, Sri Lanka, and elsewhere. In the United States, military recruiters have a strong presence on many school and college campuses, especially those in low socioeconomic neighborhoods with large numbers of immigrants and people of color. To bring this issue into the curriculum, Benesch focused a series of lessons on the question "Should colleges be allowed to bar military recruiters?" (p. 117), having students read, write, and discuss different views on the debate. Students also spoke of their own experiences being approached by military recruiters (tellingly, the Russian and Polish students had not been approached, but those from African and South American countries had).

With critical discourse inquiry, the class becomes a space for learning to identify, analyze, critique, and transform the language uses, dis- 
courses, and ways of thinking that serve to legitimate or delegitimate militarization and other forms of systemic violence. In creating learning activities and materials to foster this sort of inquiry, valuable resources include literature and news media (Morgan \& Vandrick, 2009; Song, 2004) as well as research studies of language, peace, and conflict.

\section{Experiment With Art-Based Learning}

For an example of art-based learning, we return to Wachob and Williams's (2010) study of English language programs in Egypt for transitional refugees:

One ... program used hip-hop as a way to learn English, involving students in translating rap and reggae songs and then performing them. One [student teacher] created a 12-week English book and curriculum based on 24 rap and reggae songs that students love and listen to nonstop.

Pedagogies using the visual, performing, screen, and literary arts, which are increasingly common in refugee education, seek to engage students' creative capacities, build transcultural communities, and encourage imaginative expression. The class becomes a space for rehumanizing via artful expression, and valuing orality (not just literacy). For more, see Bigelow (2010), Emert (2013), Harris (2012), and Mareng (2010). Moreover, art-based approaches can enhance not just learning but also research and teacher development in this area; see Nelson (2014) on performance methodologies pertaining to language, identity, and displacement.

\section{DIRECTIONS FOR FURTHER RESEARCH}

To strengthen the pragmatic value of TESOL's peace-conflict studies, there is an urgent need for more substantive, detailed pedagogic research, especially in three main areas. First, more research is needed on students' perspectives on learning English in conflict and postconflict environments (and, for that matter, on learning about language, peace, and conflict, though this was not our main focus here). Too few of TESOL's existing peace-conflict studies examine, or even elicit, learners' views. This odd omission of student voices leaves the field without a potentially powerful source of insights that could, and indeed should, be driving the design, delivery, and evaluation of education programs for these students. Not having students speak for 
themselves also runs the risk of victimizing, infantilizing, or further marginalizing them.

Second, more studies are needed of programs and activities for teachers' professional development on peace-conflict issues. Little is known about how, or how well, teachers are being prepared for the challenges of teaching English in an era characterized by protracted militarized conflicts and human displacement on a massive scale, despite evidence of teachers requesting professional development and resources to better manage these challenges (e.g., Windle \& Miller, 2012). Studies of teacher training and development are common in TESOL research, but few engage with ideas and experiences pertaining to militarization and displacement, even though these phenomena are becoming integral to English language education across many diverse arenas, as our investigation has shown. Now that some key challenges have been outlined, how are teacher educators incorporating these into TESOL programs, and with what results?

Lastly, more research is needed on English for military purposes. In this rapidly growing subfield of TESOL, we found a glaring dearth of rigorous empirical studies - whether ethnographic, discourse-analytic, narrative, or otherwise - of the kinds of issues that are typically investigated in great detail in other subfields (such as English for Academic Purposes); for example, students' learning needs and outcomes, curricula and materials, in-class interactions and acts of identity, teaching methodologies and technologies, and so on. Although questions have been raised about whose interests are, and are not, being served by EMP programs, the impact of these critical inquiries on mainstream thinking and practice across TESOL contexts still seems limited. Further EMP research-functional, critical, and transformative-is clearly warranted.

\section{CONCLUSION}

It has become imperative for the TESOL community to bolster what we have termed its peace-conflict studies in order to meet the ever-growing demands that the field is facing-hence this transdisciplinary, trans-sectoral review of relevant literature on conflict, militarization, and their after-effects. Our approach has allowed us to configure conflict-and-TESOL as an investigative focus and to consider this through a translocal lens, in contrast to what is more typically done, where developments are charted in just the one geo-region and/or issues are studied in just the one class, cohort, or program. Also significantly, we have theorized conflict-and-TESOL as a dynamic, dialectical relation in which conflict and its after-effects shape TESOL practice, recognizing 
also that TESOL practice has a hand in shaping conflict and its aftereffects. In this regard, we have examined two dimensions that are connected yet too rarely brought together: on the one hand, how TESOL is serving different military, security, and peacekeeping forces and, on the other hand, how people are faring as they learn or teach English in militarized zones and after they leave.

It is important to analyze these two dimensions in tandem because otherwise there is a tendency in some work to politicize the bigger picture but overlook the real-world implications for learners and teachers on the ground-or, conversely, to consider the human consequences of conflict but overlook the role that TESOL's own military-related involvements may be playing in shaping these. Our aim has been to bring these two research areas together in order to identify and illuminate some key teaching and learning challenges that are characteristic of conflict and postconflict situations. Our approach has demonstrated that these issues can be considered in a way that de-emphasizes the political particularities of a given conflict scenario and emphasizes instead the recurring pedagogic issues that require serious professional and academic attention in TESOL. This choice was purposeful and intended to maximize engagement with the material across a spectrum of political views.

As our investigation has shown, in this time of unprecedented military expenditure, TESOL programs and practitioners are actively involved in preparing soldiers and civilians for military and peacekeeping work in multilingual contexts, but these efforts are complicated by the (fraught) role of English as a lingua franca in conflict zones, given its associations with linguistic mercenaries and imperial troopers. As we have also shown, in this time of unprecedented forced displacement, a pressing challenge is to strengthen teachers' capacities to serve the needs of English language learners who either are in conflict situations or have lived through them, and who often have few material resources but abundant legacies of trauma-refugees of mind. Some of these teachers are themselves refugees and in situations as dire as their students', whereas other teachers are struggling to connect with and engage students.

In light of these challenges, we have pointed to some pedagogic approaches that can help students affected by conflict to (re)build a sense of community and belonging; to develop critical literacies and oracies for addressing real-life issues; and to recognize and foster resourcefulness, resilience, and creativity. We have also recommended more research on the following: the experiences and views of English language learners whose lives have been marked by conflict and displacement; ways of preparing English language teachers for the educational challenges that are arising as a result these local/global 
phenomena; and the practicalities, concerns, and dilemmas associated with teaching and learning English for military purposes.

Communication issues pertaining to peace, war, conflict, and security have become paramount, with everyone having a stake in these vital matters. Accordingly, we hope our investigation will foster, and help to frame, informed discussion and public debate on the nature and extent of TESOL's involvements in military endeavors and their after-effects, and in peace-building efforts as well.

Given our focus on the education challenges that result from conflict (which reflects the focus in the literature), it seems fitting to close with a study that focuses instead on the education achievements of someone displaced by conflict. When Canagarajah (2012) found himself "in the middle of the worst round of fighting between Tamil militants and the Sri Lankan army over the autonomy of the Tamil region," he was forced to flee his homeland of Sri Lanka (pp. 267-268). Relocated to the United States by the International Commission of the Red Cross, he went on to carve out an illustrious career in TESOL (which included serving as editor of TESOL Quarterly). Importantly, Canagarajah was able to draw on his own experiences of conflict and displacement in contributing (alongside colleagues) to the reconceptualizing of TESOL as a space for nurturing translanguaging and plurilingualism, an achievement that he attributes to "the boundary-crossing work of transient, migrant, and refugee teachers like me" (p. 276).

As members and stakeholders of TESOL's diverse global community come to grips with the interconnections between conflict and militarization and learning and teaching English, perhaps the professional practices and societal contributions of TESOL will be reconfigured in ways as yet unimagined.

\section{ACKNOWLEDGMENTS}

We thank the two anonymous reviewers for very astute comments on our work.

\section{THE AUTHORS}

Cynthia D. Nelson is a senior lecturer and interdisciplinary researcher at the University of Sydney's Institute for Teaching and Learning, in Sydney, Australia. Her investigations of language education focus on sexual identities and queer theory, peace and conflict, and performance and narrative in/from/as research.

Roslyn Appleby is a senior lecturer and researcher in language and international studies at the University of Technology Sydney, Australia. Her research interests include the cultural politics of English language teaching and the dynamics of intercultural gender relations, sexuality, and desire. 


\section{REFERENCES}

AMIDEAST. (n.d.). English for academic opportunity. Retrieved from http://www. amideast.org/our-work/elt/english-language-programs/english-academic-oppor tunity

Anonymous. (n.d.). Croatia: Teaching business English. One Stop English. http:// www.onestopenglish.com $/$ section .asp? theme $=$ mag\&catid $=58256 \& d o c i d=145854$

Appleby, R. (2005/2006). Mobilising and disabling the desire for empowerment: English and the transition to independence in East Timor. Southeast Asia, 6(1), 3-12. Retrieved from http://www.ubd.edu.bn/academic/faculty/FASS/SEA/ volume6.html

Appleby, R. (2009). Jane goes to Timor: How time, space and place shape English language teaching in international development. In M. Somerville, K. Power, \& P. de Carteret (Eds.), Landscapes and learning: Place studies in a global world (pp. 139-152). Rotterdam, the Netherlands: Sense.

Appleby, R. (2010). ELT, gender and international development: Myths of progress in a neocolonial world. Clevedon, England: Multilingual Matters.

Aquanaut, J. (2006, April 16). First, "ready" next "aim" finally [sic]. Dave's ESL Café. Retrieved from http://forums.eslcafe.com/teacher/viewtopic.php? $\mathrm{t}=4456$

Arditti, A. (2006, May 30). Two places, one pursuit: English teaching in Nepal and Afghanistan. Voice of America. Retrieved from http://www.voanews.com/specialenglish/archive/2006-05/2006-05-30-voa3.cfm

AusAID. (2007). Better education: A policy for Australian development assistance in education. Canberra: Australian Agency for International Development.

Baynham, M. (2006). Agency and contingency in the language learning of refugees and asylum seekers. Linguistics and Education, 17, 24-39. doi:10.1016/j. linged.2006.08.008

Benesch, S. (2010). Critical praxis as materials development: Responding to military recruitment on a U.S. campus. In N. Harwood (Ed.), English language teaching materials: Theory and practice (pp. 109-128). Cambridge, England: Cambridge University Press.

Bigelow, M. (2010). Orality and literacy within the Somali diaspora. Language Learning, 60, Supplement 1, 25-57.

British Council. (n.d.). Unit 1-British Army organisation, teacher's guide. Retrieved from http://www.britishcouncil.org/learnenglish-peacekeepers-rpme-1-britisharmy-organisation.pdf

British Council. (2013). British Council trains Namibian Defense Force members in English. Retrieved from http://www.britishcouncil.org/pep34.pdf

Brunnstrom, C. (2003). Another invasion: Lessons from international support to East Timorese NGOs. Development in Practice, 13, 310-321. doi:10.1080/ 0961452032000112374

Cadman, K., \& Brown, J. (2011). TESOL and TESD in remote Aboriginal Australia: The "true" story? TESOL Quarterly, 45, 440-462. doi:10.5054/tq.2011.256794

Canagarajah, A. S. (1993). Critical ethnography of a Sri Lankan classroom: Ambiguities in student opposition to reproduction through ESOL. TESOL Quarterly, 27, 601-626. doi:10.2307/3587398

Canagarajah, A. S. (2012). Teacher development in a global profession: An autoethnography. TESOL Quarterly, 46, 258-279. doi:10.1002/tesq.18

Clarke, M. (2006). Aid in conflict. New York, NY: Nova Science.

Clayton, S. (2008). The problem of "choice" and the construction of the demand for English in Cambodia. Language Policy, 7, 143-164. doi:10.1007/ s10993-008-9084-9 
Coffey. (2008). Coffey signs major government training contracts in the Middle East, July 2. Retrieved from http://coffey.com.au/our-news/latest-news/coffey-signsmajor-government-training-contracts-in-the-middle-east

Coleman, H. (Ed.). (2011). Dreams and realities: Developing countries and the English language. London, England: British Council.

Council on Foreign Relations. (2007). American universities in the Middle East: Agents of change in the Arab world. Retrieved from http://www.cfr.org/publication/ 12981/american_universities_in_the_middle_east.html

Department of Defence. (2012). Teaching English enhances cooperation with Australia's neighbours. Retrieved from http://news.defence.gov.au/2012/06/01/teachingenglish-enhances-cooperation-with-australia's-neighbours/

Duffield, M. (2002). Social reconstruction and the radicalization of development: Aid as a relation of global liberal governance. Development and Change, 33 , 1049-1071. doi:10.1111/1467-7660.t01-1-00260

Edge, J. (2003). Imperial troopers and servants of the lord: A vision of TESOL for the 21st century. TESOL Quarterly, 37, 701-709. doi:10.2307/3588218

Elyas, T. (2008). The attitude and the impact of the American English as a global language within the Saudi education system. Novitas-ROYAL, 2(1), 28-48. Retrieved from http:/ /www.novitasroyal.org/elyas.pdf

Emert, T. (2013). "The Transpoemations Projects": Digital storytelling, contemporary poetry, and refugee boys. Intercultural Education, 24, 355-365. doi:10.1080/ 14675986.2013 .809245

Faiq, M. (2005a, July 1). 1,001 tales. The Guardian. Retrieved from http://www. theguardian.com

Faiq, M. (2005b). Teaching English in Afghanistan. Retrieved from http://www. usingenglish.com/articles

Finn, H. B. (2010). Overcoming barriers: Adult refugee trauma survivors in a learning community. TESOL Quarterly, 44, 586-596. doi:10.5054/tq.2010. 232338

Gaffey, E. (2005). Biting your tongue: Globalised power and the international language. Variant, 2(22), 12-15.

Gilligan, A. (2012, September 15). "Poverty barons" who make a fortune from tax payer-funded aid budget. The Telegraph. Retrieved from www.telegraph. co.uk

Hajek, J. (2000). Language planning and the sociolinguistic environment in East Timor: Colonial practice and changing language ecologies. Current Issues in Language Planning, 1, 400-414. doi:10.1080/14664200008668014

Harris, A. M. (2012). Ethnocinema: Intercultural arts education. Dordrecht, the Netherlands: Springer.

Kagawa, F. (2005). Emergency education: A critical review of the field. Comparative Education, 41, 487-503. doi:10.1080/03050060500317620

Karmani, S. (2005a). English, "terror," and Islam. Applied Linguistics, 26, 262-267. doi:10.1093/applin/ami006

Karmani, S. (2005b). Petro-linguistics: The emerging nexus between oil, English, and Islam. Journal of Language, Identity, and Education, 4(2), 87-102. doi:10. $1207 /$ s15327701jlie0402_2

Kim-Rivera, E. G. (2002). English language education in Korea under Japanese colonial rule. Language Policy, 1, 261-281. doi:10.1023/A:1021144914940

Kramsch, C. (2005). Post 9/11: Foreign languages between knowledge and power. Applied Linguistics, 26, 545-567. doi:10.1093/applin/ami026

Kumaravadivelu, B. (2003). Beyond methods: Macrostrategies for language teaching. New Haven, CT: Yale University Press. 
Leshem, S., \& Trafford, V. N. (2006). Unravelling cultural dynamics in TEFL: Culture tapestries in three Israeli schools. Teachers and Teaching: Theory and Practice, 12, 639-656. doi:10.1080/13540600601029652

MacPherson, S. (2005). Negotiating language contact and identity change in developing Tibetan-English bilingualism. TESOL Quarterly, 39, 585-607. doi:10. $2307 / 3588523$

MacPherson, S. (2006). To STEAL or to TELL: Teaching English in the global era. In Y. Kanu (Ed.), Curriculum as cultural practice: Postcolonial imaginations (pp. 71-95). Toronto, Ontario, Canada: University of Toronto Press.

Mareng, C. D. (2010). Reflections on refugee students' major perceptions of education in Kakuma Refugee Camp, Kenya. Intercultural Education, 21, 473-481. doi:10.1080/14675986.2010.521392

McBeath, N. (2006). English for military purposes in the age of information technology. TESOL Law Journal, 1, 50-60.

McDermott, R. (2005, September 15). Kazakhstan opens military language institute. Eurasia Daily Monitor, 2(171). Retrieved from http://www.jamestown.org/ programs/edm

Morgan, B., \& Vandrick, S. (2009). Imagining a peace curriculum: What secondlanguage education brings to the table. Peace and Change, 34, 510-532. doi:10. 1111/j.1468-0130.2009.00598.x

Munter, J., McKinley, L., \& Sarabia, K. (2012). Classroom of hope: The voice of one courageous teacher on the US-Mexico border. Journal of Peace Education, 9 (1), 49-64. doi:10.1080/17400201.2012.657616

Nasser, I., Berlin, L. N., \& Wong, S. (Eds.). (2011). Examining education, media, and dialogue under occupation: The case of Palestine and Israel. Bristol, England: Multilingual Matters.

Nelson, C. D. (2014). Performed research for public engagement: Language and identity studies on stage. In D. N. Djenar, A. Mahboob, \& K. Cruickshank (Eds.), Language and identity across modes of communication. Boston, MA: Walter de Gruyter.

Nesyn, M. (2011). Teaching English for military purposes. In Modern trends and innovations in teaching foreign languages: Book of abstracts (pp. 154-156). Kiev: Faculty of Linguistics, National Technical University of Ukraine.

Norton, B., \& Kamal, F. (2003). The imagined communities of English language learners in a Pakistani school. Journal of Language, Identity, and Education, 2, 301-317. doi:10.1207/S15327701JLIE0204_5

Ollerhead, S. (2010). Teacher agency and policy response in the adult ESL literacy classroom. TESOL Quarterly, 44, 606-618. doi:10.5054/tq.2010.230742_1

Perlo-Freeman, S., Sköns, E., Solmirano, C., \& Wilandh, H. (2013, April). Trends in world military expenditure, 2012. SIPRI Fact Sheet. Stockholm, Sweden: Stockholm International Peace Research Institute.

Pratt, M. L. (1999). Arts of the contact zone. In D. Bartholomae \& A. Petrosky (Eds.), Ways of reading: An anthology for writers (5th ed., pp. 581-596). Boston, MA: Bedford/St. Martin's.

Rupp, R. (2009). Higher education in the Middle East: Opportunities and challenges for U.S. universities and Middle East partners. Global Media Journal, 8 (14), 5. Retrieved from http://lass.purduecal.edu/cca/gmj/index.htm

Shakhshir, K. (2011). Palestinian education under occupation: Successes and challenges. In I. Nasser, L. N. Berlin, \& S. Wong (Eds.), Examining education, media, and dialogue under occupation: The case of Palestine and Israel (pp. 3-13). Bristol, England: Multilingual Matters. 
Song, K. (2004). Conflict resolution strategy in a South Korean middle school class: Revisiting "The Three Little Pigs." Peace Research, 36(2), 77-86.

Sproat, R. (2002). A distance education program in an area of ethnic insurgency. In J. Lo Bianco (Ed.), Voices from Phnom Penh: Development and language: Global influences and local effects (pp. 303-312). Melbourne: Language Australia.

Sutton, B., \& Novkov, J. (2008). Rethinking security, confronting inequality. In B. Sutton, S. Morgen, \& J. Novkov (Eds.), Security disarmed: Critical perspectives on gender, race, and militarization (pp. 3-29). New Brunswick, NJ: Rutgers University Press.

Syed, Z. (2003). The sociocultural context of English language teaching in the Gulf. TESOL Quarterly, 37, 337-341. doi:10.2307/3588508

Talib, M. (2006, April 6). My day in Iraq: Teacher. BBC News. Retrieved from http://news.bbc.co.uk

Templer, B. (2003, June). Teaching the language of the conqueror. Z Magazine. Retrieved from http://www.zcommunications.org

Toh, G. (2003). Toward a more critical orientation to ELT in South East Asia. World Englishes, 22, 551-558. doi:10.1111/j.1467-971X.2003.00318.x

Tran, T. (2002, August 21). In impoverished Afghanistan, English becomes international language of jobs and opportunity. Global Policy Forum, 1-2. Retrieved from http:/ /www.globalpolicy.org

Tshabangu-Soko, T. S., \& Caron, R. M. (2011). English for speakers of other languages (ESOL): Improving English language acquisition for preliterate and nonliterate adult African refugees. Journal of Immigrant and Refugee Studies, 9, 416-433. doi:10.1080/15562948.2011.616812

United Nations High Commissioner for Refugees. (2013a). 2012 in review: Trends at a glance. UNHCR Global Trends 2012. Retrieved from http://www.unhcr.org

United Nations High Commissioner for Refugees. (2013b, October 1). UNHCR says it is "stretched to the limit" by the rising number of refugees. Retrieved from http://www.unhcr.org/print/524ae6179.html

USAID/Afghanistan. (2014). Education. Retrieved from http://afghanistan.usaid. gov/education

Wachob, P., \& Williams, R. S. (2010). Teaching English to refugees in transition: Meeting the challenges in Cairo, Egypt. TESOL Quarterly, 44, 596-605. doi:10. $5054 /$ tq. 2010.232341

Wallerstein, N. (1982). Language and culture in contact: Problem-posing in the ESL classroom. Reading, MA: Addison-Wesley.

Windle, J., \& Miller, J. (2012). Approaches to teaching low literacy refugee-background students. Australian Journal of Language and Literacy, 35, 317-333.

Woods, P. (2005). "The hedgehog and the fox": Approaches to English for peacekeeping in Central and Eastern Europe and Central Asia. In H. Coleman, J. Gulyamova, \& A. Thomas (Eds.), National development, education and language in Central Asia and beyond (pp. 94-99). Tashkent, Uzbekistan: British Council Uzbekistan.

Woolf, N. (2010, May 30). American liberal arts education has little to offer Iraq. The Guardian. Retrieved from http://www.theguardian.com 